Crisis and Renewal in English-Canadian Book Publishing, $1970-2004^{\mathrm{I}}$

Roy MacSkimming ${ }^{2}$

I doubt that any Canadian publisher is strong enough for any great adventures in original publishing even if the market conditions held the possibility of reward for such adventures, which they don't. The picture is much less feverish, much less dangerous, much less promising than elsewhere.

- John Gray, Writing in Canada ${ }^{3}$

To the objective observer, English-Canadian book publishing seems to operate in a perpetual state of crisis. ${ }^{4}$ It was not always that way. For many decades, the industry was modestly profitable, largely due to a captive market: students in Canada's elementary and high schools.

The industry's apparently chronic financial precariousness began in 1970 and has continued ever since. That was the year when two of the industry's longest standing pillars, the Ryerson Press and Gage Publishing - the one dating from I829, the other from 1880 - were taken over by American publishers. Almost immediately afterwards, the late Jack McClelland announced in early 197I that a similar fate could soon befall McClelland \& Stewart, the country's flagship trade publisher. ${ }^{5}$ Together, these three firms represented a substantial

I A version of this essay was delivered to the Bibliographical Society of Canada 2004 Annual Conference, McMaster University, Hamilton, 27 June 2004.

2 Roy MacSkimming is author of The Perilous Trade: Publishing Canada's Writers (Toronto: McClelland and Stewart, 2003) and other monographs, co-founder of New Press, and has served as an editor and columnist for the Toronto Star, publishing officer at the Canada Council, advisor to the Applebaum-Hébert commission on Canadian culture, and policy director for the Association of Canadian Publishers.

3 John Gray, in Writing in Canada: Proceedings of the Canadian Writers' Conference, Queen's University, 28-3I July 1955, ed. George Whalley (Toronto: Macmillan, 1956), 57.

4 For a discussion of this situation within a fuller context, see my The Perilous Trade: Publishing Canada's Writers. 
portion of English-speaking Canada's publishing establishment. At the time, a sense of crisis gripped virtually everyone concerned about our society's cultural identity. (For simplicity I'll henceforth use the terms "Canada" and "Canadian" when referring to the country's Anglophone culture.)

The 1970-71 crisis represents a watershed in our publishing industry and our cultural politics. In the thirty-four years since then, several other crisis points have occurred. (I am defining "crisis" here as a general state of financial difficulty menacing the survival of not just one publishing house, but a significant portion of the industry under Canadian control, resulting in one or more company failures.) Ironically, this timeframe has coincided with the richest period in Canada's literary history - an era of extraordinary productivity and excellence, giving us a literature now acclaimed around the world. How to reconcile these apparently conflicting trends?

\section{The Context for Crisis}

By "context," I mean the environment that makes it difficult for Canadian publishers to operate profitably. And if "crisis" seems melodramatic, let's review the roll call of culturally important, independent Canadian publishers that have disappeared since 1970: Ryerson Press (1970); Clarke, Irwin (1983); Hurtig Publishers (1991); Lester \& Orpen Dennys (199I); Western Producer Prairie Books (1991); Summerhill Press (1991); Coach House Press (1996); Macmillan of Canada (2002); Stoddart Publishing (2002); Irwin Publishing (2002); Macfarlane Walter \& Ross (2003); Gage Publishing (2003).

Specific causes of these disappearances vary case by case. But underlying all of them is the market reality referenced in the epigraph (see above) taken from the seminal 1955 Canadian Writers' Conference, concerning the risks that faced, and still face, Canadian houses publishing original manuscripts. John Gray, the head of Macmillan of Canada from 1946 to 1972 , was speaking of a time when the market for Canadian-authored books was risibly small. Even though the market has more than doubled in size since then, it remains too small, too expensive to serve, and too challenged by the

5 For an in-depth account, see George Parker's “The Sale of Ryerson Press: The End of the Old Agency System and Conflicts over Domestic and Foreign Ownership in the Canadian Publishing Industry, 1970-1986," Papers of the Bibliographical Society of Canada 40 (Autumn 2002): 7-56. 
more competitive retail prices of American books, with their greater economies of scale, to sustain a publishing industry on domestic sales alone. Other revenue sources are needed for a culturally and financially healthy industry - one capable of delivering a broad spectrum of high-quality Canadian books to readers here and abroad.

Government recognized this reality after the crisis of 1970-71. Political decisions by the federal and Ontario governments resulted in policies and programs to strengthen Canadian publishing. In 1971, the Ontario government acted on an emergency recommendation by its Royal Commission on Book Publishing to provide loan financing to McClelland \& Stewart, on the grounds that M\&S was "a national asset worthy of all reasonable public encouragement and support." The Royal Commission's final report, Canadian Publishers \& Canadian Publishing, contained a penetrating analysis of the perils of indigenous publishing, providing a decisive policy rationale for action by both levels of government.

In 1972, for the first time, both the Canada Council and the Ontario Arts Council received designated funding to support publishing. In 1973, a provincial loan-guarantee program was extended more generally to book publishers based in Ontario. In 1979, the federal government created the Book Publishing Industry Development Program to further capitalize the industry, which was continuing to suffer from low levels of debt and equity financing. Other provinces also created grant programs to support publishers in their jurisdictions.

That the political will existed to support book publishing was crucial to the industry's growth and development over the next three decades - and also to its ability to survive recurring financial crises. The network of public programs provided seed and working capital to nourish a Canadian-owned publishing ecology in all literary genres and in all parts of the country. Statistics Canada's biennial surveys of the publishing industry show that Canadian-controlled firms continue to be responsible for publishing well over $80 \%$ of all Canadianauthored titles. As Michael Ondaatje and other leading authors have stated, ${ }^{7}$ these are the publishers who have conducted the research and development of Canadian literature by nurturing new writers.

6 Ontario, Royal Commission on Book Publishing, Canadian Publishers \& Canadian Publishing (Toronto: Queen's Printer for Ontario, 1972), 287.

7 MacSkimming, The Perilous Trade, 3. 
Complementing funding programs, federal regulation preserved a certain level of domestic ownership and control. Notwithstanding these programs and policies, however, foreign-controlled multinationals such as Random House, McGraw-Hill, Pearson, Wiley, and HarperCollins continue to wield the greatest financial power in our book industry. The foundation of their success is that they are well-financed by their parent corporations and occupy the lion's share of the Canadian market in the two most lucrative areas: educational publishing and import distribution. This powerful foreign competition ensures that the great majority of indigenous publishers remain relatively small and unprofitable before grants. But they do survive.

Two things should be stressed about public funding programs. First, they are not a "welfare" safety net. The awarding of grants, and their amount, do not represent an entitlement but are tied to a firm's productivity and performance in publishing Canadian authors. Second, of the twelve disappearing publishers cited earlier, eleven vanished from the scene considerably after the advent of public support.

Clearly, then, public funding is not so lavish as to keep all Canadian publishers in business - nor should it be. Larger structural or environmental forces are at work imperiling their survival. Equally clearly, factors other than government support are also critical to their success, sustaining the impressively diverse industry that we have today. The balance of this essay will identify forces working both against and for Canadian publishers in fulfilling their vocation.

\section{Historical Forces Working against Canadian Publishers}

At least four larger historical forces were behind the disappearance of publishers since 1970: fundamental changes in textbook purchasing, in the economy, in government policy, and in retail bookselling.

\section{Changes in Textbook Purchasing}

The sales of Ryerson and Gage in 1970, and the bankruptcy of Clarke, Irwin in 1983, were consequences of changes in provincial textbook buying. These changes began in the biggest market for educational publishers, Ontario. Around 1969, the Ontario Ministry of Education amalgamated school boards and removed its textbook stimulation grants. These grants had provided boards with a set amount per pupil to be spent on books.

All three of the firms suffered because they were primarily textbook publishers. All had other problems, too. Ryerson was lumbered with 
a money-losing printing operation and an inflexible owner in the United Church of Canada. Gage had a longstanding family ownership that had lost interest in publishing. And Clarke, Irwin had a secondgeneration leadership that tried to adapt to the new circumstance by re-orienting the firm to the more risky venture of trade publishing, but the strategy failed - in spite of public assistance.

\section{Changes in the Economy}

In 1991, Canada's economy was in recession, exacerbated by the federal government's introduction of the Goods and Services Tax (GST). The book market, naturally, was not immune. That was the crisis year when we lost two leading western publishers, Hurtig and Western Producer Prairie Books, and a major literary and trade publisher, Lester \& Orpen Dennys. Hurtig was a critical presence as the originator of The Canadian Encyclopedia, the most important popular reference-work ever published in this country. The firm couldn't sustain losses resulting from unexpectedly low sales of its children's encyclopedia. L\&OD fell victim to the inattention of its new owner, financier Christopher Ondaatje. The Western Producer newspaper, owned by the Saskatchewan Wheat Pool, was busy cutting costs. So the specific situations of these three firms varied, but the common factor was a severely depressed market.

\section{Changes in Government Policy}

If government can give, it can also take away. The giving came in 1992, in response to the 1991 crisis just mentioned. That year, the same Conservative federal government that had introduced the GST responded to vigorous industry lobbying by tripling funding for the Book Publishing Industry Development Program (from approximately $\$ 8$ million to $\$ 25$ million). It also replaced the postal subsidy for mailing Canadian books with the \$25-million Publications Distribution Assistance Program (PDAP), which subsidized both publishers' and booksellers' expenses of distributing books.

The taking away came only three years later. In 1995, as part of its draconian "program review" budget, the Liberal federal government precipitously slashed funding from these programs by over half, cutting the PDAP altogether. Meanwhile, Ontario's new government under Conservative Premier Mike Harris axed the 23-year-old loan-guarantee program for publishers. Given little warning of these measures, publishers were forced to cut back their 
Canadian publishing programs and staffing levels. Coach House Press, probably the country's most prestigious literary press at that time, was forced to go out of business in 1996. Alarm over that loss in the cultural community encouraged a new federal culture minister, Sheila Copps, to restore the lost funding over the next two years.

\section{Changes in Retail Bookselling}

Book publishers are heavily interdependent with booksellers, but the marriage is not always a happy one. It became miserable after 1995, when Chapters Inc. amalgamated the two remaining national bookstore chains, Coles and SmithBooks, then opened a formidable chain of over seventy superstores across the country. Enormous market power became concentrated in one set of hands. By 2000, Chapters was seriously abusing that power by excessively delaying payments to publishers, then returning unprecedented quantities of unsold books in lieu of cash.

The whole Canadian publishing industry suffered from these practices, which were only somewhat mitigated by a merger between Chapters and its rival, Indigo Books \& Music, in 200I. But an eventual casualty of these quasi-monopolistic practices was Stoddart Publishing and its distribution arm, General Distribution Services (GDS). These firms went bankrupt in 2002, precipitating yet another major crisis. It involved the extinction of the largest Canadian-owned book publisher-distributor - a grievous loss in itself. But it also visited extreme financial hardship on over 60 smaller Canadian publishers whose books were distributed by GDS. These houses - ranging from Douglas \& McIntyre and Key Porter through ECW and McGillQueen's to small literary presses such as Porcupine's Quill and Cormorant Books - lost millions of dollars in sales that GDS owed them, as well as lost sales opportunities during the drawn-out legal proceedings of the receivership. Consequently, the survival of a large segment of Canadian publishing was in serious doubt.

The federal and Ontario governments reacted to the crisis by stepping in with emergency bridge financing. Their action was essential to the publishers' ability to carry on; but government assistance amounted to considerably less than half the lost revenue. Although the industry has shown remarkable resilience in coping with this latest crisis, publishers who survived the GDS collapse have become the walking wounded - much weaker financially than if circumstances had remained "normal." 


\section{Forces Working For Canadian Publishers}

And yet, the publishing industry's ability to renew itself is striking. I would suggest that the reasons for this go well beyond support from public coffers. The industry has developed notable strengths that help ensure its survival. Each of these strengths has contributed to the industry's growth, maturation, and longevity. I will identify four such factors:

\section{Creative excellence across genres}

A major contributor to many Canadian publishers' survival is the excellence of their product. Simply put, our publishers are very good at what they do. Publishers must be more skilled and resourceful to survive in Canada, with its severe market constraints; and if they can make it in this country, as Publishers Weekly once noted, they can make it anywhere. ${ }^{8}$ Our books are known at home and abroad for their excellence, whether in editing, design, or production. The artistry developed by Canada's writers over the past two generations is matched by the craft accumulated by our publishers.

That excellence is distributed with remarkable even-handedness among genres: literary and commercial fiction (mysteries, fantasy, romances); serious and commercial non-fiction; children's literature, both picture-books and young-adult titles; and illustrated and art books. Canada's publishing output ranks with the best in the world. This is not just a personal opinion, but is reflected in our recent successes in winning international literary awards, and in Canadian-controlled publishers' booming export sales in the $1990 \mathrm{~s}$ (see below).

\section{Regional and Generic Diversity}

To an exceptional degree, the Canadian-owned publishing industry is diverse and owner-managed. Its decentralization beyond the traditional publishing capital of Toronto is unusual in an era of globalization and concentration of ownership. Partly this is due to public funding and the existence of Canadian ownership regulations. But this diversity also reflects the nation's regional and cultural makeup.

8 Baker, John F., "Canada: If You Can Make It Here, You'll Make It Anywhere," Publishers Weekly, 25 May 1998: 4I-52. 
Regional publishers do not exist solely to produce books about their region, although that is certainly one of their editorial strengths. Some of the country's largest and most successful English-language publishers are based in Vancouver. Significant firms are located in Victoria, Edmonton, Calgary, Winnipeg, Montreal, Fredericton, Halifax, St. John's, and other cities. Like Ontario, both British Columbia and Alberta contain "national" publishing industries in microcosm, with a wide variety of houses publishing across a spectrum of literary, general trade, scholarly, educational, children's, and Aboriginal books. This diversity is a great strength, both for our literary culture and the publishing industry itself: it maximizes the discovery and development of writing resources for different markets, in ways that an industry concentrated in one city could not.

\section{Export}

Selling to international markets has become critical to the survival of many Canadian publishers. Our publishers export Canadian writing either as finished books (chiefly to the U.S. and other English-speaking countries) or in the form of foreign-rights sales. In recent years, export revenues have been a lifesaver for many firms, compensating for domestic sales ravaged by the retail problems mentioned above, or offsetting financial troubles stemming from the Stoddart / GDS collapse. The Association for the Export of Canadian Books reports that Canadian-controlled publishers' total foreign revenue increased by $231 \%$ between 1993 and 2000 .

A frequently asked question is why Canadian publishers are not more profitable, given that Canadian authors are almost routinely winning international prizes and becoming literary stars abroad. The answer is that, in the case of many of these authors, their Canadian publishers do not control their international rights. For authors, it is more lucrative to have their literary agents sell publishing rights to their works country by country, or language by language. Consequently, Canadian publishers' sales of their books are often confined to the domestic market; in such cases, the publisher's only monetary benefit comes indirectly, in the form of heightened publicity for the book at home. If they can, Canadian publishers naturally do seek to control world rights to their titles, enabling them to act as the author's agent worldwide; but that is frequently not possible, especially with the more successful authors, such as Margaret Atwood, Rohinton Mistry, or Ann-Marie MacDonald. 


\section{Distribution}

Physical distribution of books in the domestic market is important in two ways. Most Canadian publishers, particularly smaller ones, contract with larger publisher-distributors to efficiently fulfill orders for their books from retailers, libraries, schools, and other customers. Especially since the GDS bankruptcy, and the attendant financial and legal problems, publishers have learned the importance of a sound business relationship with their distributor. The lessons learned have helped publishers to craft distribution agreements that protect their business and financial interests.

The other sense in which distribution is important is that some large and successful Canadian firms base their operations on providing distribution services to other publishers, Canadian and foreign. They have effectively adapted an older business model - the "agency system." That system was discarded by many Canadian publishers in the 1970 and later. But firms attempting it more recently have grown larger and more profitable as a result. Significant examples include Raincoast Books, Firefly Books, Thomas Allen, and the largest such Canadian-owned firm, H.B. Fenn. These companies invest more of their resources in distribution than publishing, giving them a more solid and more diversified revenue base; but they also publish books with their profits from distribution. That such firms can become strong publishers in their own right is shown by Raincoast's and Thomas Allen's increasingly ambitious Canadian programs, funded by distribution revenues from Harry Potter and other imported titles. The point is also illustrated by the recent purchase of Key Porter Books in June 2004 by H.B. Fenn.

The experience of surviving publishers, such as Jack David of ECW Press, ${ }^{9}$ leads me to add a fifth factor - sheer perseverance and moral courage. Canadian publishers are an extraordinarily dedicated bunch.

\section{Conclusion}

This analysis of the forces pushing and pulling Canada's book publishers through more than three decades demonstrates some of

9 Jack David, "The Perfect Storm: How ECW Survived Three Bankruptcies," a paper presented to the Bibliographical Society of Canada Annual Conference, McMaster University, Hamilton, 27 June 2004. 
the historical changes that have swept through the industry. It also demonstrates that our publishers have important strengths on their side. Those strengths, and the lessons learned from successive waves of crisis and change, should equip this key engine of our culture to adapt successfully to the inevitable next crisis - whatever form it may take.

\section{RÉSUMÉ}

Au Canada anglophone l'édition a subi des crises successives depuis 1970. Malgré cela elle demeure productive tant au plan de la création qu'à celui de la culture. Les fonds publics ont joué un rôle important pour ce qui est de faire profiter l'industrie et d'en assurer la stabilité de manière significative. Quoiqu'il en soit la situation était telle pour les livres canadiens qu'il en est résulté la perte de nombreuses et importantes maisons d'édition. Cet article brosse un tableau des forces qui ont joué contre l'industrie, notamment des changements fondamentaux et imprévus dans le domaine de l'achat des manuels, les politiques gouvernementales, l'économie et la vente de livres au détail. Pour contrebalancer ces défis, des forces ont joué en faveur de l'industrie, notamment l'excellence au plan de la création, la diversité au plan des régions et des genres, ainsi qu'une adaptation fructueuse dans le domaine des ventes à l'étranger et de la distribution au pays. Soulignant le dévouement des éditeurs canadiens en tant que facteur crucial, cet article conclue avec optimisme en soulignant leur capacité à faire face à de futures crises. 